\title{
Yin Yang 1 is associated with cancer stem cell transcription factors (SOX2, OCT4, BMI1) and clinical implication
}

\author{
Samantha Kaufhold ${ }^{1}$, Hermes Garbán ${ }^{2^{*}}$ and Benjamin Bonavida ${ }^{1^{*}}$
}

\begin{abstract}
The transcription factor Yin Yang 1 (YY1) is frequently overexpressed in cancerous tissues compared to normal tissues and has regulatory roles in cell proliferation, cell viability, epithelial-mesenchymal transition, metastasis and drug/immune resistance. YY1 shares many properties with cancer stem cells (CSCs) that drive tumorigenesis, metastasis and drug resistance and are regulated by overexpression of certain transcription factors, including SOX2, OCT4 (POU5F1), BMI1 and NANOG. Based on these similarities, it was expected that YY1 expression would be associated with SOX2, OCT4, BMI1, and NANOG's expressions and activities. Data mining from the proteomic tissue-based datasets from the Human Protein Atlas were used for protein expression patterns of YY1 and the four CSC markers in 17 types of cancer, including both solid and hematological malignancies. A close association was revealed between the frequency of expressions of YY1 and SOX2 as well as SOX2 and OCT4 in all cancers analyzed. Two types of dynamics were identified based on the nature of their association, namely, inverse or direct, between YY1 and SOX2. These two dynamics define distinctive patterns of BMI1 and OCT4 expressions. The relationship between YY1 and SOX2 expressions as well as the expressions of BMI1 and OCT4 resulted in the classification of four groups of cancers with distinct molecular signatures: 1) Prostate, lung, cervical, endometrial, ovarian and

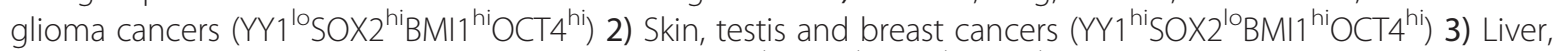
stomach, renal, pancreatic and urothelial cancers (YY1 ${ }^{\text {lo }} \mathrm{SOX} 2^{\mathrm{lo}} \mathrm{BMI} 1^{\text {hi }} \mathrm{OCT} 4^{\text {hi }}$ ) and 4) Colorectal cancer, lymphoma and melanoma ( $\mathrm{YY} 1^{\text {his }} \mathrm{SOX} 2^{\text {hi }} \mathrm{BMI} 1^{\text {lo } O C T 4^{\text {hi }}}$ ). A regulatory loop is proposed consisting of the cross-talk between the NF-KB/PI3K/AKT pathways and the downstream inter-regulation of target gene products YY1, OCT4, SOX2 and BMI1.
\end{abstract}

Keywords: BMI1, Cancer stem cells, NANOG, OCT4, SOX2, Yin Yang 1

\section{Background}

General properties of cancer stem cells (CSCs)

Drug resistance and metastatic spread are two key characteristics of tumors that make cancer so difficult to eradicate. Tumors are comprised of heterogeneous cell subpopulations, and these subsets respond distinctly and differently to various therapeutics [1]. One subset of these cells consists of cancer stem cells (CSCs), which are largely similar to normal stem cells with respect to both their behavior and their regulation [2]. CSCs are

\footnotetext{
* Correspondence: hgarban@ucla.edu; bbonavida@mednet.ucla.edu ${ }^{2}$ NantBioScience, Inc, NantWorks, LLC \& California NanoSystems Institute (CnSI), University of California Los Angeles, Los Angeles, CA 90095, USA 'Department of Microbiology, Immunology, and Molecular Genetics, David Geffen School of Medicine, University of California Los Angeles, Los Angeles, CA 90095, USA
}

pluripotent, capable of self-renewal, highly resistant to cytotoxic therapies, and drive tumorigenesis.

In addition to different cellular responses, adaptive changes like the epithelial to mesenchymal transition (EMT) exacerbate metastatic spread and drug resistance. EMT is the process by which epithelial cells lose their apico-basolateral polarity to become migratory mesenchymal cells. This process is crucial to embryonic differentiation but is dysregulated in cancer, affording tumor cells invasive and migratory properties. EMT has been shown to cause reversion to a CSC-like phenotype, linking CSCs, EMT and drug resistance $[3,4]$.

Clearly, better molecular and biochemical understandings of the phenotypic and functional properties of CSCs will help in the development of novel and specific targeted therapeutics to eradicate CSCs. Thus, these should 
reduce the inherent resistance and relapses and should prolong survival. Below, we briefly present reported studies on the various regulatory factors in the development of CSCs.

\section{CSC markers}

The sex determining region Y-box 2 (SOX2), POU class 5 homeobox 1 (POU5F1), B cell-specific Moloney murine leukemia virus insertion site 1 (BMI1) and Nanog homeobox (NANOG) genes are four genes encoding transcription factors that have been reported to be involved in the regulation of CSCs. SOX2, Octamerbinding transcription factor 4 (OCT4) (the transcription factor encoded by POU5F1, also known as POU5F1) and NANOG make up the core transcriptional network responsible for the regulation of stem cell self-renewal and pluripotency [5].

\section{SOX2}

a) General properties of SOX2 The SOX2 gene is located on chromosome 3q26.3q27 [6, 7]. The SOX2 protein is composed of 317 amino acids and has a mass of $34.3 \mathrm{kDa}$ [8]. Originally characterized in 1994, SOX2 is a member of the SOXB1 family of transcription factors, and its three primary domains are an $\mathrm{N}$-terminal domain, a high-mobility group (HMG) domain, and a transactivation domain [9]. Protein partners, nuclear import signals, and nuclear export signals bind the HMG domain, while the $\mathrm{C}$-terminal transactivation domain is responsible for promoter binding, causing the activation or repression of target genes [10].

b) SOX2 expression in various cancers SOX2 is expressed in neural stem cells [11], breast stem cells [12], and stem populations in the liver, pancreas, and stomach [13]. SOX2 overexpression in recurrent prostate cancer tissues has been reported [14]. SOX2 is likewise overexpressed in head and neck squamous cell carcinoma [15]. Bioinformatics analysis showed SOX2 overexpression in 7/36 solid tumors analyzed [16].

Multiplication of the 3q26.3 gene locus causes SOX2 amplification, which has been reported in glioblastoma, small-cell lung cancer and many squamous cell carcinomas [17-24]. Co-amplification of SOX2 and Protein Kinase $\mathrm{C}_{\mathrm{I}}\left(\mathrm{PRKC}_{\mathrm{I}}\right)$ has been reported to be responsible for the CSC phenotype in lung squamous cell carcinoma [25]. Additionally, FGF induces SOX2 in osteoblasts [26].

c) SOX2 functions

In pancreatic cancer cells, SOX2 overexpression causes increased cell proliferation via cyclin D3 induction [27]. Subsequent SOX2 knockdown causes transcriptional induction of $\mathrm{p} 21^{\mathrm{Cip} 1}$ and $\mathrm{p} 27^{\mathrm{Kip} 1}$, resulting in cell cycle arrest and cell growth inhibition [27]. Similarly, SOX2 silencing inhibits cellular proliferation in lung squamous cell carcinoma cells [28]. The upregulation of BMP4, which acts as a tumor suppressor, is responsible for this inhibition of proliferation [28]. SOX2 silencing causes a decrease in cell proliferation and loss of tumorigenicity in glioblastoma tumor-initiating cells in immunodeficient mice [29]. SOX2 has also been reported to promote cellular proliferation in breast, prostate, and cervical cancers, among others [30-32]. Furthermore, SOX2 has been implicated in the evasion of apoptotic signals in prostate cancer, gastric cancer and NSCLC [32-34]. SOX2 has been reported to promote invasion, migration, and metastasis in melanoma, colorectal cancer, glioma, gastric cancer, ovarian cancer and hepatocellular carcinoma [20, 35-38]. SOX2 mediates invasive and migratory phenotypes, in part, through MMP3, MMP2, and PI3K/AKT/mTOR activations [35, 37, 39].

d) Regulation of SOX2

The ubiquitin-specific protease 22 (USP22) represses the SOX2 promoter in embryonic differentiation [40]. Activation of EGFR signaling increases SOX2 expression and self-renewal in prostate CSCs [41]. Furthermore, an EGFR/STAT3/SOX2 signaling pathway has been reported in murine breast cancer stem cells [42]. In primary melanoma cells, GLI1 and GLI2 have been reported to bind the proximal SOX2 promoter, indicating that SOX2 is regulated, in part, by Hedghog-GLI signaling [43]. The PI3K/Akt signaling pathway has been shown to be activated in prostate cancer cells overexpressing SOX2 [44]. By contrast, ovarian adenocarcinoma cells overexpressing SOX2 have been reported to possess an inhibited PI3K/Akt signaling pathway [45]. These conflicting results suggest that PI3K/Akt modulation may have an important role in the expression of SOX2.

e) Clinical implications

SOX2 overexpression is correlated with tumor recurrence, poor prognosis and chemoresistance in head and neck squamous cell carcinoma [15]. SOX2 overexpression increases tumorigenicity and inhibits differentiation in neuroblastoma [46]. High SOX2 expression is associated with higher histological grade in esophageal squamous cancer $(p<0.001)$ [47]. A significant correlation $(p<0.001)$ between high SOX2 expression and decreasing patient survival was also established in the same study [47]. In contrast, SOX2 has been shown to correlate with improved survival and better patient outcome in lung cancer [48-53]. The expressions of SOX2, OCT4 and NANOG correlate positively with the pathological grade of gliomas [54]. 


\section{OCT4}

a) General properties of OCT4

The POU5F1 gene is located on chromosome 6p21.33

$[6,55]$. There are 6 related pseudogenes on chromosomes 1, 3, 8, 10 and 12 [56], and alternative splicing results in multiple protein isoforms. The canonical OCT4 protein sequence contains 360 amino acids and weighs $38.6 \mathrm{kDa}$ [8]. OCT4, also referred to as POUF51 and OCT3/4, is another transcription factor necessary for maintaining pluripotency [57]. The POU domain is the main active domain for OCT4. The POU domain is composed of two subdomains, an amino-terminal POU specific region and a carboxylterminal homeodomain, and both bind DNA through helix-turn-helix structures [58].

b) OCT4 expression in various cancers OCT4 is overexpressed in recurrent prostate cancer tissues [14]. Bioinformatics analysis showed OCT4 overexpression in 9/36 of different solid tumor types when compared to corresponding normal tissues [16]. Namely, OCT4 was overexpressed in bladder, brain, lung, ovarian, pancreatic, prostate, renal, seminoma and testicular cancers. OCT4 overexpression was observed in $1 / 4$ hematological cancers-namely, chronic lymphocytic leukemia-in the same study [16].

c) OCT4 functions

OCT4 works synergistically with SOX2, among other factors, to regulate transcription. SOX2 and OCT4 are both activators of genes involved in pluripotency, including themselves and NANOG, and repressors of genes involved in differentiation (e.g., HOXB1, PAX6, MYF5) [59, 60]. SOX2 and OCT4 interact directly to activate target gene transcription [61]. OCT4/SOX2 heterodimers bind the NANOG proximal promoter region to induce transcription [62, 63].

d) Regulation of OCT4 SOX2 and OCT4 regulate their own transcription by binding the composite sox-oct elements in the SOX2 and POU5F1 enhancers [64]. In pluripotent stem cells, Foxm 1 directly binds the POU5F1 promoter $-3 \mathrm{~kb}$ upstream region [65]. Among others, SALL4, ESRRB, and PAF1 have been implicated as positive regulators of OCT4 expression, while TCF3, GCNF, HIF and CDK2 have been identified as negative regulators [66].

e) Clinical implications

Like high SOX2 expression, high OCT4 expression is associated with higher histological grade in esophageal squamous cancer $(p<0.001)$ [47]. Both NANOG and OCT4 overexpressions are associated with both advanced cancer stage and decreased survival in oral squamous cell and lung adenocarcinomas [67].

\section{NANOG}

a) General properties of NANOG

The NANOG gene is located on chromosome 12p13.31 [6, 7, 55]. The 2184-nucleotide NANOG cDNA encodes the NANOG protein [68]. While there are 11 NANOG pseudogenes [69], only pseudogene 8 has an open reading frame capable of producing the functional NANOG protein [69-72]. The canonical NANOG protein has a sequence of 305 amino acids and a mass of $34.6 \mathrm{kDa}$ [8]. Another isoform, NANOG-delta 48, lacks amino acids 168183 and is, consequently, 289 amino acids long [8].

b) NANOG expression in various cancers

Both pluripotent mouse and human stem cell lines express NANOG mRNA, but NANOG mRNA is absent from differentiated cells [73]. NANOG protein levels have been reported to be elevated in oral squamous cell carcinoma tumor tissues as compared to corresponding normal tissues $(p=$ 0.014) [74].

c) NANOG functions

NANOG is capable of maintaining embryonic stem cell pluripotency independently of the LIF-STAT3 pathway, which OCT4 is incapable of doing $[68,73]$. NANOG exerts many functions through its transcriptional regulatory activities. NANOG regulates the cell cycle and proliferation by directly binding the cyclin D1 promoter $[75,76]$. In prostate cancer cell lines, the induction of NANOG causes the upregulations of CD133 and ALDH1 [77]. NANOG alone is sufficient to induce SLUG transcription [67]. Furthermore, NANOG is capable of inducing CSClike properties in primary p53-deficient mature mouse astrocytes; however, astrocytes with intact p53 could not be induced [78]. Some functional redundancy and cooperation between NANOG and STAT3 have been reported. The two form a complex in head and neck squamous cell carcinoma cells [79], and microarray analysis showed that NANOG also regulated 14 out of the 22 STAT3 target genes involved in the maintenance of an undifferentiated state [80].

SOX2, OCT4 and NANOG co-occupy the promoter regions of at least 353 genes, and NANOG has been shown to occupy $>90 \%$ of the promoter regions bound by both OCT4 and SOX2 in human embryonic stem cells [59]. More explicitly, in $>90 \%$ of the cases where a promoter region is bound by both OCT4 and SOX2 in human embryonic stem cells, NANOG is also present. 
d) Regulation of NANOG

In addition to OCT4/SOX2 heterodimers, NANOG is regulated at a transcriptional level by multiple factors. GLI1 and GLI2 activate NANOG transcription by directly binding cis-regulatory sequences of the NANOG gene in neural stem cells [81]. In mouse embryonic stem cells, p53 was shown to suppress NANOG transcription in response to DNA damage. P53 directly binds the NANOG promoter through two consensus binding motifs [82]. LIF-induced STAT3 phosphorylation also results in the upregulation of NANOG in embryonic stem cells [83].

e) Clinical implications Increased nuclear NANOG expression has been associated with high-grade subtypes of ovarian cancer and poor disease-free survival [84]. Additionally, NANOG overexpression is correlated with poor prognoses for colorectal and breast cancer patients, as well as for ovarian cancer patients [85-87].

\section{$B M I 1$}

a) General properties of BMI1

Ensembl identifies the BMI1 gene as located on chromosome 10p12.2. The BMI1 protein is composed of 326 amino acids and has a mass of $36.9 \mathrm{kDa}$ [8]. BMI1 is a member of the polycomb repressive complex 1 (PRC1), which also includes Mel-18, Mph1/Rae28, M33, Scmh1, and Ring 2. The polycomb repressive complex 2 (PRC2) is comprised of EED, EZH, Sux12 and YY1 [88].

b) BMI1 expression in various cancers BMI1 expression levels have been reported to be high in many tissues, including the brain, esophagus, kidney, lungs, and blood, among others [89]. BMI1 levels are also elevated in various solid tumorforming cancers, among them neuroblastoma and bladder cancer [90, 91].

c) BMI1 functions

BMI1 is involved in the maintenance and/or selfrenewal of many stem cell types, including embryonic, neural, hematopoietic and prostate [92-95]. BMI1 promotes the proliferation of leukemic stem cells in mouse models [96], and BMI1 activates the self-renewal ability of neural stem cells [97]. BMI1 is directly responsible for the regulation of multiple targets. BMI1 regulates the tumor suppressors p16INK4a and p14ARF [98, 99]. BMI1 also directly binds the PTEN promoter, resulting in the activation of the PI3K/AKT pathway and subsequently SNAIL stabilization and EMT induction [100]. Additionally, BMI1 directly occupies the $C D H 1$ promoter, causing E-cadherin repression [100].
In endometrial cancer cells, the loss of BMI1 results in the reduced expression of SOX2 and KLF4 [101]. CD133+ breast CSCs with high SLUG expression have been shown to also have high BMI1 expression [102]. Furthermore, BMI1 cooperates with TWIST1 to promote cancer dedifferentiation and metastasis [103]. BMI1 overexpression correlates with NANOG overexpression, high-grade status and increased selfrenewal in breast adenocarcinomas [104].

d) Regulation of BMI1 Multiple major regulatory pathways, including Akt, Wnt and Notch, contribute to the regulation of BMI1 [105]. Additionally, the Hedgehog pathway activates BMI1 in breast stem cells [106].

e) Clinical implications Elevated BMI1 RNA levels have been correlated with more advanced chronic myeloid leukemia status [96, 107]. Increased levels of BMI1 are correlated with poor prognoses in head and neck cancers [103], including in nasopharyngeal carcinoma patients [108]. BMI1 is further correlated with radio- and chemoresistance in head and neck squamous cell carcinomas and is considered to be a predictive factor for overall survival [109]. In glioma, BMI1 expression inversely correlates with survival and positively correlates with poor prognosis [110]. In non-Hodgkin B-cell lymphoma patients, BMI1 expression is associated with poor outcome as well [111].

\section{CSC markers' associations with drug resistance}

Each of the CSC markers discussed above are implicated in resistance to cancer treatments. In breast cancer, SOX2 silencing restores tamoxifen sensitivity [112]. NANOG overexpression, likewise, increases drug resistance in breast cancer cell lines [77]. Lung adenocarcinoma cell lines are sensitized to erlotinib by shRNA-knockdown of SOX2 [50]. Overexpressions of NANOG and OCT4 also afford lung adenocarcinoma cells a high tolerance to cisplatin [67]. The overexpression of NANOG promotes cisplatin resistance in esophageal cancer [113], and siRNAknockdown of NANOG increases sensitivity to cisplatin [114]. The elevated expressions of NANOG and OCT4 correlate with cisplatin resistance and recurrence in oral squamous cell carcinoma [115]. SOX2 has been implicated in paclitaxel resistance in prostate cancer cell lines [44]. Docetaxel sensitivity is increased in prostate cancer cells by silencing BMI1 [116]. Ovarian CSCs are more resistant to cisplatin and paclitaxel when BMI1 is overexpressed [117], and targeting BMI1 sensitizes ovarian cancer cells to cisplatin [118]. Furthermore, CD44+/CD24+ pancreatic cancer cells expressing high levels of BMI1 are largely resistant to gemcitabine [119]. 


\section{Yin Yang 1 (YY1) and its relationship with CSC transcription factors}

\section{General characteristics of YY1}

Yin Yang 1 (YY1) is an ubiquitously expressed zincfinger transcription factor encoded by the $23 \mathrm{~kb} Y Y 1$ gene [120-124]. Comprised of 414 amino acids, YY1 exerts various cellular functions, including transcriptional regulation, cell proliferation, chromatin remodeling and apoptosis [124-128]. YY1 regulates multiple targets, including ERBB2, p53, caspases and HDACs, which are implicated in cancer progression [127].

YY1 is overexpressed in many types of cancer, including metastatic breast cancer [129, 130], colon cancer [131], gastric cancer [132] and prostate cancer [133]. Patterns of YY1 protein expression levels in human cancers have been reviewed previously [134]. The enrichment of binding sites for YY1 and NANOG was identified in the interactomes of both SOX2 and POU5F1 [135]. Additionally, YY1 upregulates NANOG in gastric cancer [136]. YY1 has been previously reported to directly interact with embryonic ectoderm development (EED), a protein of the same PcG family as BMI1 [137].

\section{YY1 and its relationship to CSC transcription factors}

There exist similar patterns of overexpression in various cancerous tissues between the four CSC markers (SOX2, OCT4, BMI1 and NANOG) and YY1. For example, the overexpressions of YY1 [133], SOX2 and OCT4 [14] in prostate cancer cell lines have been reported. These findings suggested that there may be a functional correlation between YY1 and the CSC markers (Fig. 1). Furthermore, the binding site enrichment and interactions with NANOG and EED suggest that YY1 may be associated with the CSC transcription factors [135-137].

\section{Data mining from proteomic datasets}

Publicly available proteomics datasets were used to assess whether YY1, SOX2, OCT4, NANOG and BMI1 expressions correlated in both solid tumors $(n=16)$ and hematological malignancies $(n=1)$ [138].

1. SOX2, OCT4, NANOG and BMI1 were chosen as representative CSC markers because of their welldocumented roles in stem cell maintenance as well as data availability [5, 59, 92-95].

The Human Protein Atlas' Cancer Atlas feature provides antibody staining information for many proteins in various cancerous tissues [139]. The antibodies used by the Human Protein Atlas for this staining analysis are summarized in Table 1 . The Cancer Atlas feature was interrogated to assess the antibody staining of YY1, SOX2, OCT4, NANOG and BMI1 in different cancer types. In each case, the protein of interest was searched in the Cancer Atlas. The resulting "staining overview" presented the antibody staining profile, which differentiated stains into high, medium, low or not detected groups, for the protein in twenty types of cancers, namely, breast, carcinoid, cervical, colorectal, endometrial, glioma, head and neck, liver, lung, lymphoma, melanoma, ovarian, pancreatic, prostate, renal, skin, stomach, testis, thyroid and urothelial cancers. The three cancers with sample sizes fewer than four-carcinoid, head and neck, and thyroid-were discarded, bringing the total types of cancers considered herein to seventeen.

2. Example profile

SOX2 staining qualified as 0/12 high, 1/12 medium, 9/ 12 low and 2/12 not detected in breast cancer. In this case, 12 different tissues were stained from 12 different patients. A binary system was then applied such that only high or medium scores were considered positive staining. To assess the percentage of positive staining, the number of "positive" (high or medium) stains was divided by the total number of stains performed. In the SOX2 case presented above, ( 0 high +1 medium $) / 12$ stains yields $1 / 12$ positive staining.

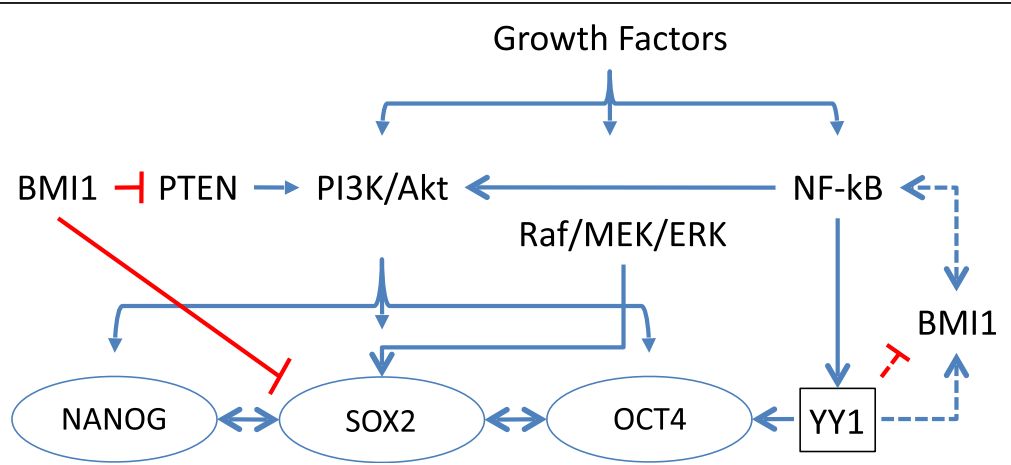

Fig. 1 Hypothesized cross-talk between $Y Y 1$ and CSC transcription factors. This model reflects prior findings and proposed linkages between $Y Y 1$ and CSC markers 
Table 1 Selected antibodies characteristics

\begin{tabular}{|c|c|c|c|c|c|}
\hline & $\begin{array}{l}\text { YY1 antibody } \\
\text { HPA001119 }\end{array}$ & $\begin{array}{l}\text { SOX2 antibody } \\
\text { CAB010648 }\end{array}$ & $\begin{array}{l}\text { NANOG antibody } \\
\text { CAB019380 }\end{array}$ & $\begin{array}{l}\text { BMl1 antibody } \\
\text { CAB011120 }\end{array}$ & $\begin{array}{l}\text { OCT4 antibody } \\
\text { CAB026380 }\end{array}$ \\
\hline Provider & $\begin{array}{l}\text { Atlas Antibodies, } \\
\text { Sigma-Aldrich }\end{array}$ & Chemicon & SDIX & Upstate & SDIX \\
\hline Product name & HPA001119 & AB5603 & 2929.00.02 & $05-637$ & 3542.00 .02 \\
\hline Host species & Rabbit & Rabbit & Rabbit & Mouse & Rabbit \\
\hline Clonality & $\mathrm{pAb}$ & pAb & msAb & $\mathrm{mAb}$ & msAb \\
\hline Antigen & $\begin{array}{l}\text { Recombinant } \\
\text { protein fragment }\end{array}$ & Synthetic peptide & $\begin{array}{l}\text { Genetic } \\
\text { immunization }\end{array}$ & $\begin{array}{l}\text { Recombinant } \\
\text { protein }\end{array}$ & $\begin{array}{l}\text { Genetic } \\
\text { immunization }\end{array}$ \\
\hline Cross reactivity & YY2 (80 \%) & N/A & N/A & N/A & N/A \\
\hline
\end{tabular}

\section{Example analysis}

Breast cancer can be used as an example to illustrate the complete process used by us for analysis for one cancer type. The Human Protein Atlas' Cancer Atlas reported that YY1 antibody HPA001119 yielded 2 high, 5 medium, 1 low and 1 not detected stains in this type of cancer. Consequently, high and medium scores comprised 7 out of a total 9 stains. In this case, $78 \%$ of the stains were above the binary threshold and considered positive staining. YY1 antibody CAB009392 yielded 0 high, 6 medium, 5 low and 0 not detected stains, so the positive staining was $6 / 11$ or $55 \%$. As previously described, the SOX2 antibody CAB010648 profile was 0 high, 1 medium, 9 low and 2 not detected stains. Only $1 / 12$ stains exceeded the binary threshold for $8 \%$ positive staining. NANOG antibody CAB019380 was never detected in breast cancer and had $0 \%$ positive staining. By these same processes, it was determined that BMI1 antibody HPA030472 had 10/11 (91\%), BMI1 antibody CAB011120 had 8/10 (80 \%), OCT4 antibody CAB025600 had 11/11 (100 \%) and OCT4 antibody CAB026380 had 5/9 (55 \%) positive staining.

4. Antibody selection

We have selected only one antibody staining profile for each protein that was stained by two different antibodies. This choice was based on the recommendation of the Human Protein Atlas itself and was performed for the sake of simplifying ensuing analyses. The final antibodies used were YY1 antibody HPA001119, SOX2 antibody CAB010648, NANOG antibody CAB019380, BMI1 antibody CAB011120 and OCT4 antibody CAB026380 (Table 1). Of note, YY1 antibody HPA01119 appears to show crossreactivity with related protein YY2 (based on an $80 \%$ amino acid homology), and thus, cross-reactivity between family members by the various antibodies used must be considered with the results. It is impossible to ignore the possibilities that the noted expression correlations are instead between YY2 and CSC transcription factors, or that there is a functional redundancy between $Y Y 1$ and YY2 that cannot be distinguished. To that end, the development of YY1specific antibodies is necessary to validate these findings in vitro. Western blots should be conducted to confirm these findings experimentally.

5. Further analyses

These procedures were repeated for each antibody in each type of cancer and used to produce binary expression graphs and corresponding statistical analyses. The example breast cancer binary frequency of the protein expression graph was used as a prototype (Fig. 2). The binary expression graphs only show the positive staining derived from the

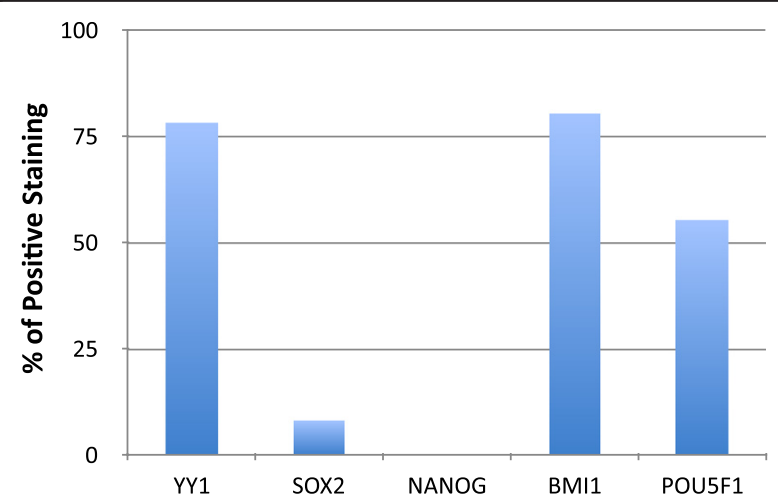

Fig. 2 Example of a represented binary percentages of positive staining (frequency of protein expression) in breast cancer. Staining was categorized as high, medium, low or not detected for each antibody by the Human Protein Atlas (proteinatlas.org). For the purposes of applying a binary system of enumeration, only high or medium scores were considered positive staining. The number of these positive stains was divided by the number of total stains performed to ascertain the percentage of positive staining. For example, for YY1 antibody HPA001119, there were 2 high and 5 medium scores. That comprises 7 out of a total 9 stains for a total of $78 \%$ positive staining. The graph compares these percentages of positive staining for each antibody - YY1 antibody HPA001119, YY1 antibody CAB009392, SOX2 antibody CAB010648, NANOG antibody CAB019380, BMI1 antibody HPA030472, BMI1 antibody CAB011120, POU5F1 antibody CAB025600 and POU5F1 antibody CAB026380-in breast cancer 
high and medium staining of each antibody in breast cancer. Two-factor without replication analysis of variance was applied to analyze the source of variation between the different antibody staining figures. Pearson correlations were performed to compare the staining of each antibody of each marker to the others. Post-hoc t-tests also assessed the significance between YY1 and CSC marker expressions. From these data, patterns of YY1, SOX2, OCT4, NANOG and BMI1 protein expressions were elucidated and evaluated.

\section{Clustered expression analyses}

Through the grouping of marker expression patterns, our analyses identified four distinct tiers of cancers (Additional file 1: Figure S1). Initially, two distinct dynamics were identified: in clusters one and two, YY1 and SOX2 expressions share an inverse relationship, while in clusters three and four, YY1 and SOX2 expressions have a strong direct correlation. The two types of relationship between YY1 and SOX2 expression appear to dictate distinctive patterns of expression of BMI1 and OCT4. These patterns of expression between YY1, SOX2, OCT4 and BMI1 were used to classify the four tiers.

\section{Tier 1}

The first group consists of prostate, lung, cervical, endometrial and ovarian cancers as well as glioma. This group shows low YY1 expression with concomitant high SOX2, BMI1 and OCT4 expressions (Fig. 3). Of note,

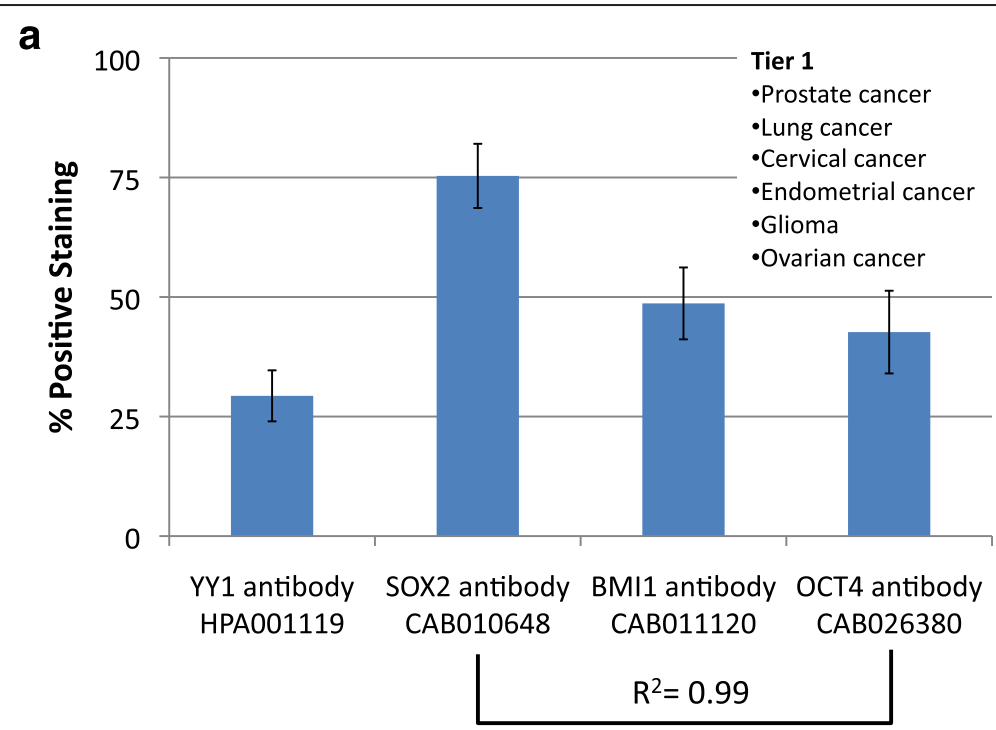

b

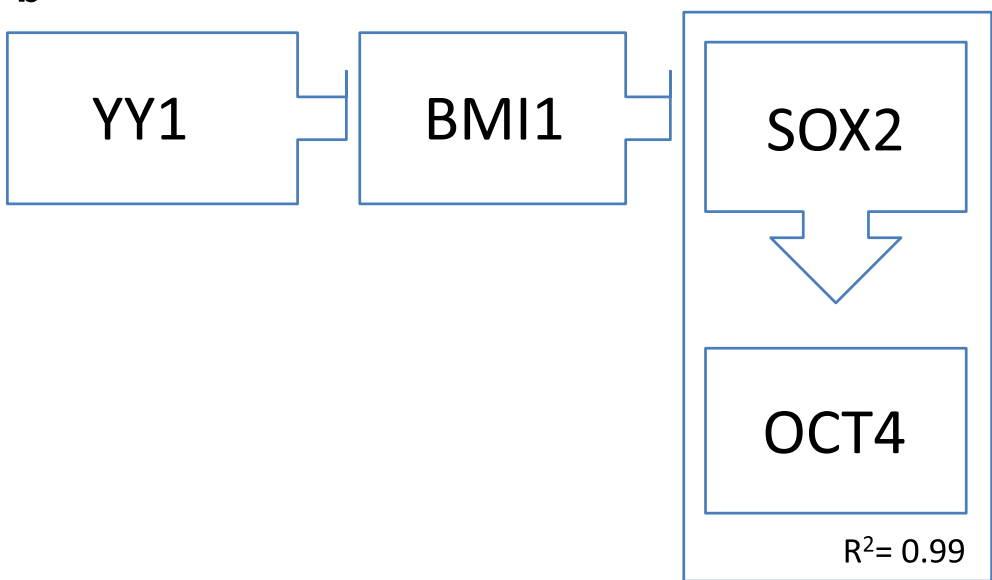

Fig. 3 a Frequency of Protein expression. Antibody staining for glioma, prostate, lung, cervical, endometrial, and ovarian cancers (Tier 1). SOX2 and OCT4 have a strong direct correlation $\left(R^{2}=0.99\right)$. $\mathbf{b}$ Hypothetical functional dynamic of CSC-related transcription factors. Correlations of the frequency of protein expression in a segregated malignancies tier 
comparison of SOX2 and OCT4 expressions yields an $\mathrm{R}^{2}$ value of 0.99 , indicating a strong direct correlation.

\section{Tier 2}

Tier two, characterized by high YY1 and low SOX2, is found in skin, testis and breast cancers. SOX2 and BMI1 have a strong inverse correlation $\left(R^{2}=-1.0\right)$ and $Y Y 1$ has a direct correlation with OCT4 expression $\left(R^{2}=0.7\right)$. These findings show an overall pattern of high YY1, low SOX2, high BMI1 and high OCT4 (Fig. 4).

\section{Tier 3}

Liver, stomach, renal, pancreatic and urothelial cancers make up the third tier. This cluster has low YY1 and low SOX2 expressions. SOX2 and OCT4 have a strong inverse correlation $\left(\mathrm{R}^{2}=-0.9\right)$, and BMI1 and OCT4 also have an inverse correlation $\left(\mathrm{R}^{2}=-0.7\right)$. This group has a molecular signature of low YY1 and SOX2 with high BMI1 and OCT4 (Fig. 5).

\section{Tier 4}

The fourth tier has high YY1 and high SOX2. This group consists of colorectal cancer, lymphoma and melanoma. YY1 and SOX2 both share strong direct correlations with OCT4 expression $\left(\mathrm{R}^{2}=1.0\right.$ and 0.8 , respectively). In this case, YY1, SOX2 and OCT4 all have high expressions while BMI1 has low expression (Fig. 6).

\section{Overarching results}

Taken together, tiers one and two show a strong inverse correlation between YY1 and SOX2 $\left(R^{2}=-0.9\right)$. On the contrary, tiers three and four show a strong direct

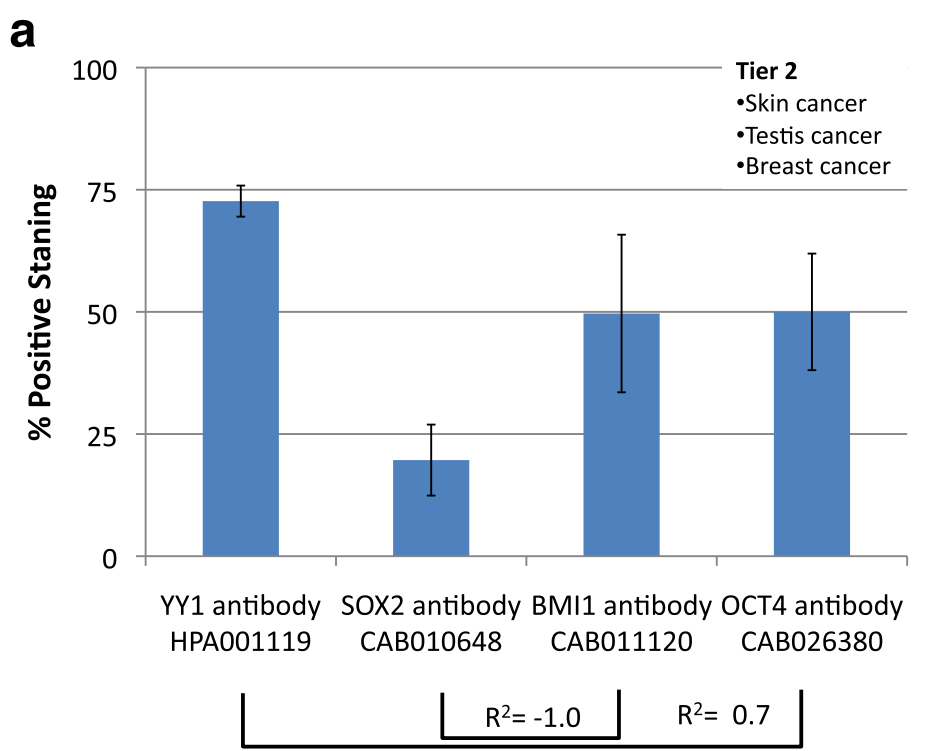

b

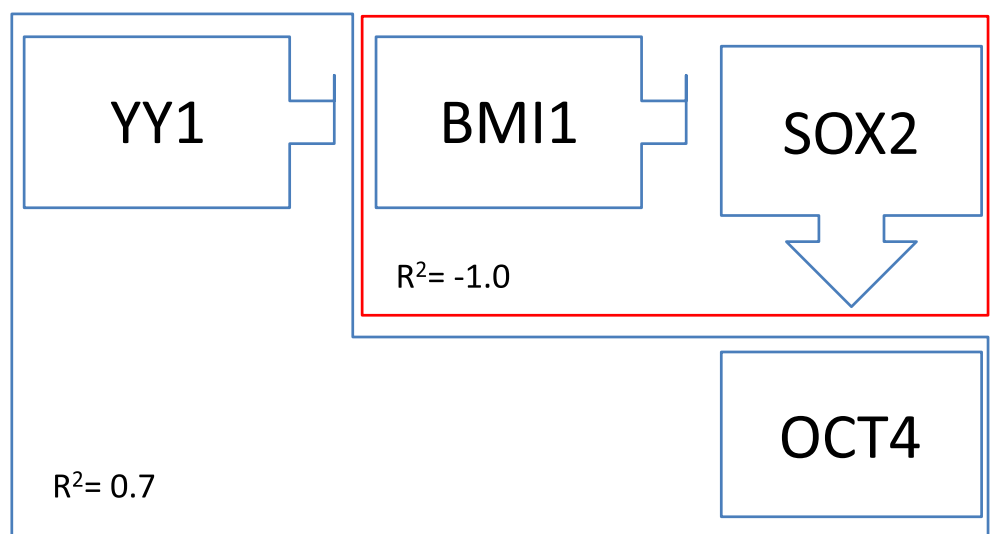

Fig. 4 a Frequency of Protein expression. Antibody staining for skin, testis and breast cancers (Tier 2). YY1 is positively associated with OCT4 $\left(R^{2}=\right.$ $0.7)$, while SOX2 is negatively associated with BMI1 $\left(R^{2}=-1.0\right)$. b Hypothetical functional dynamic of CSC-related transcription factors. Correlations of the frequency of protein expression in a segregated malignancies tier 


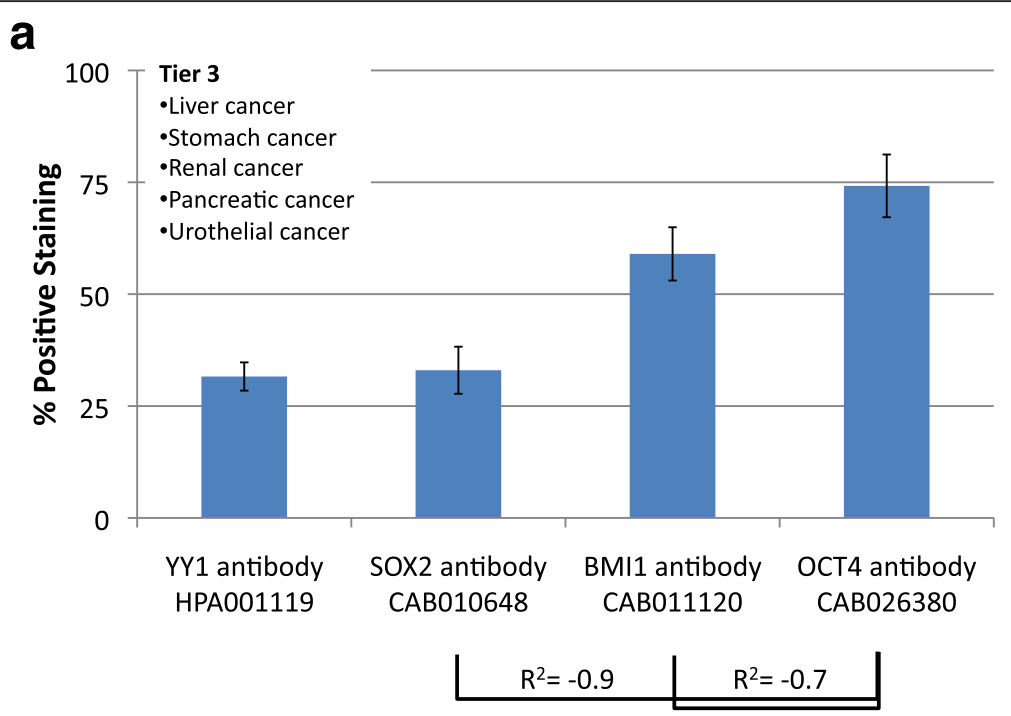

b

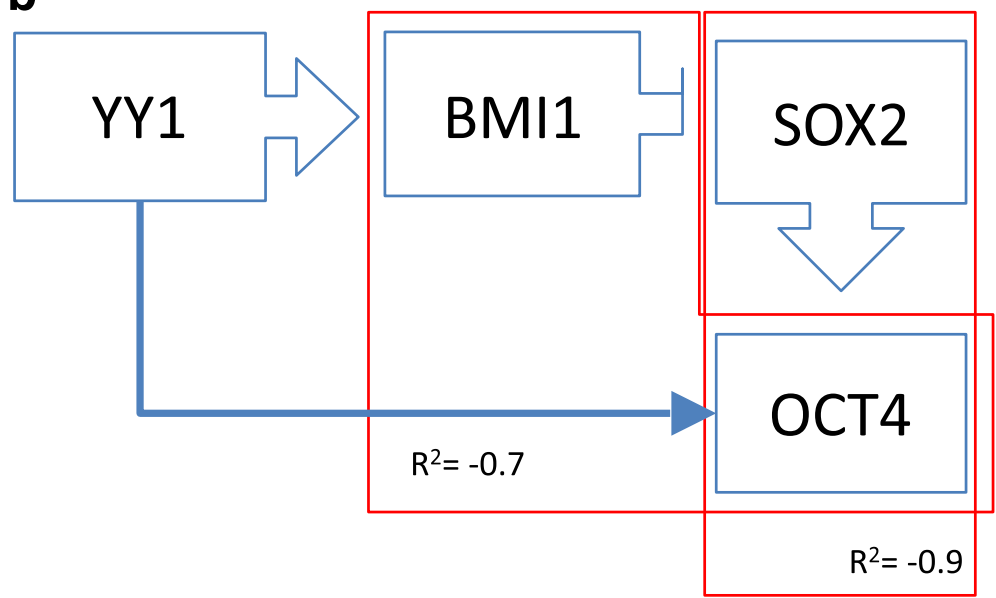

Fig. 5 a Frequency of Protein expression. Antibody staining for liver, stomach, renal, pancreatic and urothelial cancers (Tier 3). There are significant negative correlations between SOX2 and OCT4 $\left(R^{2}=-0.9\right)$ as well as between BMI1 and OCT4 $\left(R^{2}=-0.7\right)$. $\mathbf{b}$ Hypothetical functional dynamic of CSC-related transcription factors. Correlations of the frequency of protein expression in a segregated malignancies tier

correlation between YY1 and SOX2 expressions $\left(\mathrm{R}^{2}=0.8\right)$. These associations were the initial basis for the distinctions among the four tiers. The tiers were then further subdivided based on the specific frequency of expression patterns of BMI1 and OCT4. When tiers three and four are grouped together, such that the results from liver, stomach, renal, pancreatic, urothelial cancers, lymphoma and melanoma are pooled, there is also a strong inverse correlation between $\mathrm{YY} 1$ and BMI1 expressions $\left(\mathrm{R}^{2}=\right.$ -0.7). YY1 expression correlates strongly and differentially with the CSC markers' expression in the different tiers.

\section{Conclusions, implications and speculations}

YY1 frequency of expression was associated with the SOX2, BMI1 and OCT4 frequency of expression across many cancers, though the type of association varied. The differential patterns of the four markers' expressions among the different tiers can be explained by the dual nature of YY1's activities as both an activator and a repressor and in a direct or an indirect manner. We have examined the putative regulatory regions (promoters) of BMI1, SOX2, POU5F1 (OCT4) and YY1 for potential YY1 binding sites and reciprocal control of each other in a combinatorial matrix by using SABioscience's TextMining Application [140] and data from the University of California, Santa Cruz (UCSC) Genome Browser [141] in order to define predicted binding sites associations of transcription factors to their regulatory regions. Our analysis demonstrated the presence of putative YY1 binding sites on all of the regulatory regions of the interrogated transcription factors (i.e., BMI1, SOX2, OCT4) including YY1 itself. However, none of the putative transcription binding sites for BMI1, SOX2, OCT4 were found on the YY1 or on each other's regulatory regions. 


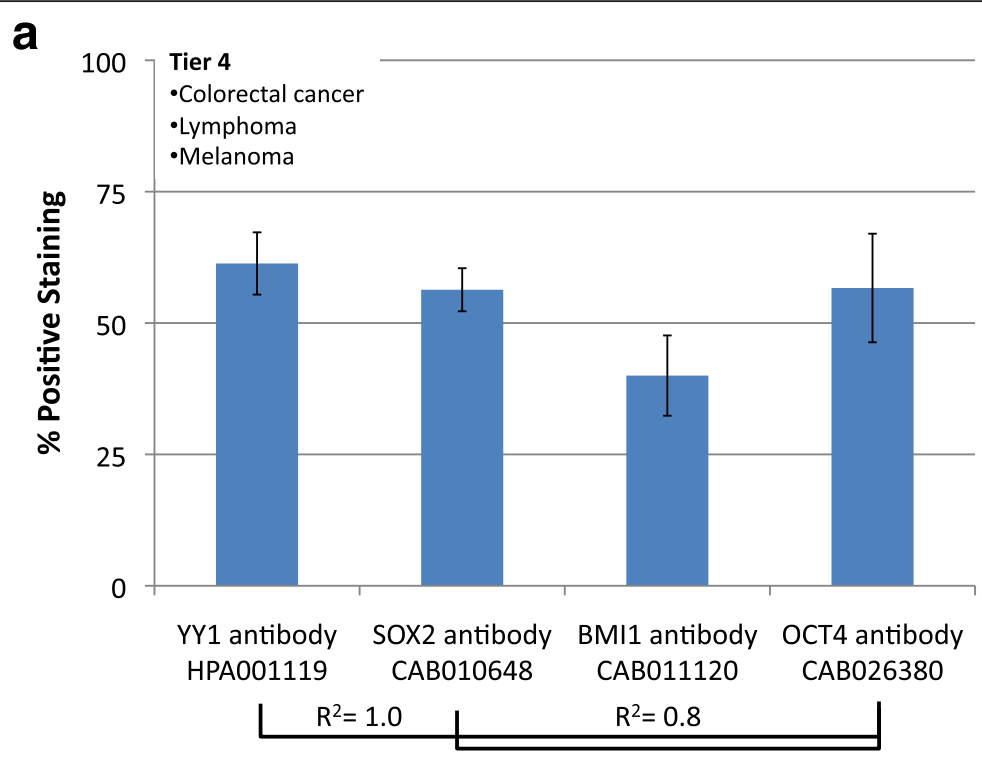

b

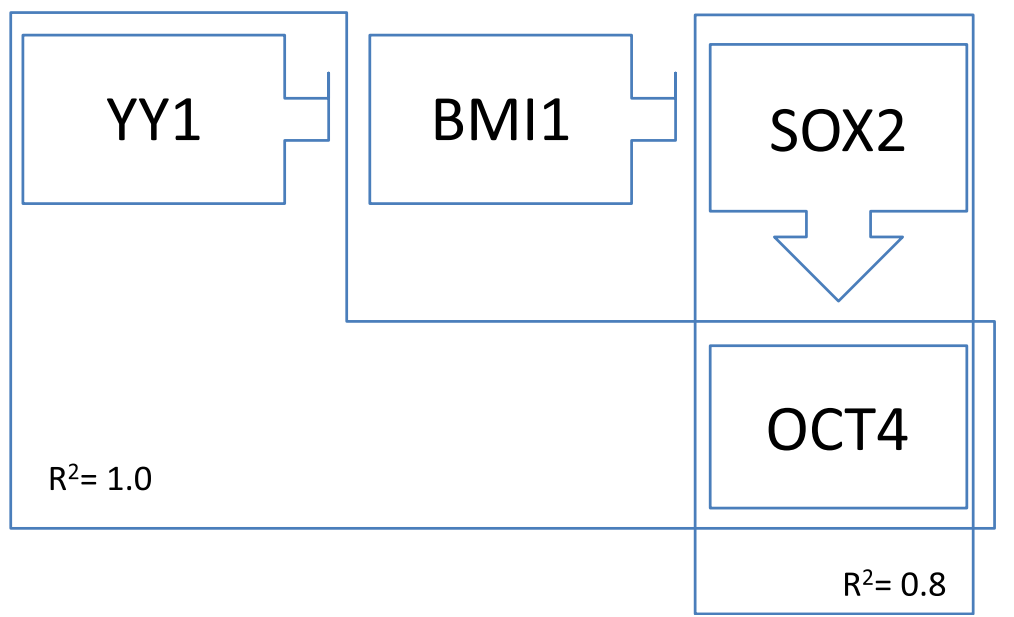

Fig. 6 a Frequency of Protein expression. Antibody staining for colorectal cancer, lymphoma and melanoma (Tier4). There are strong positive associations between YY1 and OCT4 $\left(R^{2}=1.0\right)$ as well as between SOX2 and OCT4 $\left(R^{2}=0.8\right)$. $\mathbf{b}$ Hypothetical functional dynamic of CSC-related transcription factors. Correlations of the frequency of protein expression in a segregated malignancies tier

Noteworthy, a strong association (predicted binding site) was noted between NF- $\mathrm{kB}$ on the YY1 regulatory region and also between YY1 on the BMI1 promoter, suggesting a plausible transcriptional control by these factors.

The transcriptional association of YY1 on the regulatory regions of BMI1, SOX2, OCT4 and YY1 suggests a multi-dynamic regulatory control of expression. There is an NF- $\mathrm{kB}$-mediated induction of expression of YY1 that can: a) inhibit the transcription of BMI1 and increase the expression of SOX2, resulting in up-regulation of OCT4 (e.g., Tier 1, Tier 2 and Tier 4 of the clustered groups); or b) activate the transcription of BMI1 and decrease the expression of SOX2, resulting in downregulation of OCT4; or c) directly activate transcription of OCT4 (e.g., Tier 3 of clustered groups). Overall, the majority of the malignancies examined in this study have YY1 as a potential transcriptional repressor acting on CSCs-associated transcription factors.

It is important to note that the association of YY1 and CSC transcription factors was based on analysis of expression patterns on whole tumor tissues and not on the CSC subsets. Clearly, additional studies are necessary to determine whether the associations seen on whole tumor tissues is also found in the CSC subsets of the various cancers examined herein. The validation of YY1's association with CSC markers and their functional roles in CSC regulation may provide new insights on the role of YY1 in carcinogenesis and its potential as a therapeutic target. 


\section{Additional file}

Additional file 1: Figure S1. Clustered Expression Association. Results were cluster-associated in 4 groups (tiers) based on the percentage of positive staining (Frequency of protein expression). Green boxes, $\geqq 50 \%$ positive staining. Blue boxes, $<50 \%$ positive staining. (JPG $66 \mathrm{~kb}$ )

\section{Abbreviations}

Akt: protein kinase B; BMI1: B cell-specific Moloney murine leukemia virus insertion site 1; CSCs: cancer stem cells; EMT: epithelial-mesenchymal transition; NF-kB: nuclear factor kappa-B; PI3K: phosphatidylinositol 3-kinase; POUF51: POU class 5 homeobox 1; SOX2: sex determining region Y-box 2; YY1: Ying Yang 1.

\section{Acknowledgments}

The authors also acknowledge the research support for the reported publications used in this review and include: the Jonsson Comprehensive Cancer Center at UCLA; the University of California Gene Medicine Program; the UCLA AIDS Institute; the NCI-RO1-CA133479; NCICA107023-02S1; NCICA05715213S1: NIHR21149938.

\section{Authors' contributions}

SK was responsible for data collection and drafting the manuscript. HG contributed to study design, data analysis and manuscript editing. BB conceived of the project and edited the manuscript. All authors approved of the final manuscript.

\section{Competing interests}

The authors declare that they have no competing interest.

\section{Received: 29 January 2016 Accepted: 9 May 2016}

Published online: 25 May 2016

\section{References}

1. Zhou BB, Zhang H, Damelin M, Geles KG, Grindley JC, Dirks PB. Tumourinitiating cells: challenges and opportunities for anticancer drug discovery. Nat Rev Drug Discov. 2009;8(10):806-23.

2. Lobo NA, Shimono Y, Qian D, Clarke MF. The biology of cancer stem cells. Annu Rev Cell Dev Biol. 2007;23:675-99.

3. Mani SA, Guo W, Liao MJ, Eaton EN, Ayyanan A, Zhou AY, Brooks M, Reinhard F, Zhang CC, Shipitsin M, et al. The epithelial-mesenchymal transition generates cells with properties of stem cells. Cell. 2008;133(4): 704-15.

4. Polyak K, Weinberg RA. Transitions between epithelial and mesenchymal states: acquisition of malignant and stem cell traits. Nat Rev Cancer. 2009:9(4):265-73.

5. Kanehisa M, Goto S, Sato Y, Kawashima M, Furumichi M, Tanabe M. Data information, knowledge and principle: back to metabolism in KEGG. Nucleic Acids Res. 2014;42(Database issue):D199-205.

6. HUGO Gene Nomenclature Committee (HGNC).http://www.genenames.org.

7. Entrez Gene [http://www.ncbi.nlm.nih.gov/gene]

8. Uniprot [http://www.uniprot.org]

9. Stevanovic M, Zuffardi O, Collignon J, Lovell-Badge R, Goodfellow P. The CDNA sequence and chromosomal location of the human SOX2 gene. Mamm Genome. 1994:5(10):640-2.

10. Weina K, Utikal J. SOX2 and cancer: current research and its implications in the clinic. Clin Transl Med. 2014;3:19.

11. Thiel G. How Sox2 maintains neural stem cell identity. Biochem J. 2013:450(3):e1-2

12. Hassiotou F, Beltran A, Chetwynd E, Stuebe AM, Twigger AJ, Metzger P, Trengove N, Lai CT, Filqueira L, Blancafort $P$, et al. Breastmilk is a novel source of stem cells with multilineage differentiation potential. Stem Cells. 2012;30(10):2164-74

13. Sherwood RI, Chen TY, Melton DA. Transcriptional dynamics of endodermal organ formation. Dev Dyn. 2009;238(1):29-42.

14. Guzel E, Karatas OF, Duz MB, Solak M, Ittmann M, Ozen M. Differential expression of stem cell markers and $A B C G 2$ in recurrent prostate cancer Prostate. 2014:74(15):1498-505.

15. Lee SH, Oh SY, Do SI, Lee HJ, Kang HJ, Rho YS, Bae WJ, Lim YC. SOX2 regulates self-renewal and tumorigenicity of stem-like cells of head and neck squamous cell carcinoma. Br J Cancer. 2014;111(11):2122-30.
16. Schoenhals M, Kassambara A, De Vos J, Hose D, Moreaux J, Klein B. Embryonic stem cell markers expression in cancers. Biochem Biophys Res Commun. 2009;383(2):157-62.

17. Hussenet $T$, Dali S, Exinger J, Monga B, Jost B, Dembele D, Martinet $N$ Thibault C, Huelsken J, Brambilla E, et al. SOX2 is an oncogene activated by recurrent 3q26.3 amplifications in human lung squamous cell carcinomas. PLOS ONE. 2010;5(1):e8960

18. Albertson DG. Gene amplification in cancer. Trends Genet. 2006:22(8):447-55.

19. Annovazzi L, Mellai M, Caldera V, Valente G, Schiffer D. SOX2 expression and amplification in gliomas and glioma cell lines. Cancer Genomics Proteomics. 2011;8(3):139-47.

20. Alonso MM, Diez-Valle R, Manterola L, Rubio A, Liu D, Cortes-Santiago N, Urquiza L, Jauregi P, Lopez de Munain A, Sampron N, et al. Genetic and epigenetic modifications of Sox2 contribute to the invasive phenotype of malignant gliomas. PLoS ONE. 2011:6(11), e26740.

21. Bass AJ, Watanabe H, Mermel CH, Yu S, Perner S, Verhaak RG, Kim SY, Wardwell L, Tamayo P, Gat-Viks I, et al. SOX2 is an amplified lineage-survival oncogene in lung and esophageal squamous cell carcinomas. Nat Genet. 2009:41(11):1238-42

22. Maier S, Wilbertz T, Braun M, Scheble V, Reischl M, Mikut R, Menon R,

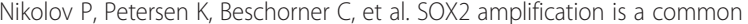
event in squamous cell carcinomas of different organ sites. Hum Pathol. 2011;42(8):1078-88.

23. Rudin CM, Durinck S, Stawiski EW, Poirier JT, Modrusan Z, Shames DS, Bergbower EA, Guan Y, Shin J, Guillory J, et al. Comprehensive genomic analysis identifies SOX2 as a frequently amplified gene in small-cell lung cancer. Nat Genet. 2012;44(10):1111-6.

24. Freier K, Knoepfle K, Flechtenmacher C, Pungs S, Devens F, Toedt G, Hofele C, Joos S, Lichter P, Radlwimmer B. Recurrent copy number gain of transcription factor SOX2 and corresponding high protein expression in oral squamous cell carcinoma. Genes Chromosomes Cancer. 2010;49(1):9-16

25. Justilien $\mathrm{V}$, Walsh MP, Ali SA, Thompson EA, Murray NR, Fields AP. The PRKC and SOX2 oncogenes are coamplified and cooperate to activate Hedgehog signaling in lung squamous cell carcinoma. Cancer Cell. 2014;25(2):139-51.

26. Mansukhani A, Ambrosetti D, Holmes G, Cornivelli L, Basilico C. Sox2 induction by FGF and FGFR2 activating mutations inhibits Wnt signaling and osteoblast differentiation. J Cell Biol. 2005;168(7):1065-76.

27. Herreros-Villanueva M, Zhang JS, Koenig A, Abel EV, Smyrk TC, Bamlet WR, de Narvajas AA, Gomez TS, Simeone DM, Bujanda L, et al. SOX2 promotes dedifferentiation and imparts stem cell-like features to pancreatic cancer cells. Oncogenesis. 2013;2, e61.

28. Fang WT, Fan CC, Li SM, Jang TH, Lin HP, Shih NY, Chen CH, Wang TY, Huang SF, Lee AY, et al. Downregulation of a putative tumor suppressor BMP4 by SOX2 promotes growth of lung squamous cell carcinoma. Int J Cancer. 2014;135(4):809-19.

29. Gangemi RM, Griffero F, Marubbi D, Perera M, Capra MC, Malatesta P, Ravetti GL, Zona GL, Daga A, Corte G. SOX2 silencing in glioblastoma tumorinitiating cells causes stop of proliferation and loss of tumorigenicity. Stem Cells. 2009;27(1):40-8.

30. Stolzenburg S, Rots MG, Beltran AS, Rivenbark AG, Yuan X, Qian H, Strahl BD Blancafort P. Targeted silencing of the oncogenic transcription factor SOX2 in breast cancer. Nucleic Acids Res. 2012;40(14):6725-40.

31. Ji J, Zheng PS. Expression of Sox2 in human cervical carcinogenesis. Hum Pathol. 2010;41(10):1438-47.

32. Jia X, Li X, Xu Y, Zhang S, Mou W, Liu Y, Liu Y, Lv D, Liu CH, Tan X, et al. SOX2 promotes tumorigenesis and increases the anti-apoptotic property of human prostate cancer cell. J Mol Cell Biol. 2011;3(4):230-8.

33. Hutz K, Mejias-Luque R, Farsakova K, Ogris M, Krebs S, Anton M, Vieth M, Schuller U, Schneider MR, Blum H, et al. The stem cell factor SOX2 regulates the tumorigenic potential in human gastric cancer cells. Carcinogenesis. 2014;35(4):942-50.

34. Chen S, Li X, Lu D, Xu Y, Mou W, Wang L, Chen Y, Liu Y, Li X, Li LY, et al. SOX2 regulates apoptosis through MAP4K4-survivin signaling pathway in human lung cancer cells. Carcinogenesis. 2014;35(3):613-23.

35. Han X, Fang $X$, Lou X, Hua D, Ding W, Foltz G, Hood L, Yuan Y, Lin B. Silencing SOX2 induced mesenchymal-epithelial transition and its expression predicts liver and lymph node metastasis of CRC patients. PLoS ONE. 2012:7(8), e41335.

36. Sun C, Sun L, Li Y, Kang X, Zhang S, Liu Y. Sox2 expression predicts poor survival of hepatocellular carcinoma patients and it promotes liver cancer cell invasion by activating Slug. Med Oncol. 2013;30(2):503. 
37. Girouard SD, Laga AC, Mihm MC, Scolyer RA, Thompson JF, Zhan Q, Widlund HR, Lee CW, Murphy GF. SOX2 contributes to melanoma cell invasion. Lab Invest. 2012;92(3):362-70.

38. Lou X, Han X, Jin C, Tian W, Yu W, Ding D, Cheng L, Huang B, Jiang H, Lin B. SOX2 targets fibronectin 1 to promote cell migration and invasion in ovarian cancer: new molecular leads for therapeutic intervention. OMICS. 2013;17(10):510-8

39. Yang $N$, Hui L, Wang $Y$, Yang $H$, Jiang $X$. SOX2 promotes the migration and invasion of laryngeal cancer cells by induction of MMP-2 via the PI3K/Akt/ mTOR pathway. Oncol Rep. 2014;31(6):2651-9.

40. Sussman RT, Stanek TJ, Esteso P, Gearhart JD, Knudsen KE, McMahon SB. The epigenetic modifier ubiquitin-specific protease 22 (USP22) regulates embryonic stem cell differentiation via transcriptional repression of sexdetermining region Y-box 2 (SOX2). J Biol Chem. 2013;288(33):24234-46.

41. Rybak AP, Tang D. SOX2 plays a critical role in EGFR-mediated selfrenewal of human prostate cancer stem-like cells. Cell Signal. 2013; 25(12):2734-42

42. Yang J, Liao D, Chen C, Liu Y, Chuang TH, Xiang R, Markowitz D, Reisfeld RA, Luo Y. Tumor-associated macrophages regulate murine breast cancer stem cells through a novel paracrine EGFR/Stat3/Sox-2 signaling pathway. Stem Cells. 2013:31(2):248-58.

43. Santini R, Pietrobono S, Pandolfi S, Montagnani V, D'Amico M, Penachioni JY, Vinci MC, Borgognoni L, Stecca B. SOX2 regulates self-renewal and tumorigenicity of human melanoma-initiating cells. Oncogene. 2014;33(38): 4697-708.

44. Li D, Zhao LN, Zheng XL, Lin P, Lin F, Li Y, Zou HF, Cui RJ, Chen H, Yu XG. Sox2 is involved in paclitaxel resistance of the prostate cancer cell line PC-3 via the PI3K/Akt pathway. Mol Med Rep. 2014;10(6):3169-76.

45. Li Y, Chen K, Li L, Li R, Zhang J, Ren W. Overexpression of SOX2 is involved in paclitaxel resistance of ovarian cancer via the PI3K/Akt pathway. Tumour Biol. 2015

46. Yang S, Zheng J, Xiao X, Xu T, Tang W, Zhu H, Yang L, Zheng S, Dong K, Zhou G, et al. SOX2 promotes tumorigenicity and inhibits the differentiation of I-type neuroblastoma cells. Int J Oncol. 2015;46(1):317-23.

47. Wang Q, He W, Lu C, Wang Z, Wang J, Giercksky KE, Nesland JM, Suo Z. Oct3/4 and Sox2 are significantly associated with an unfavorable clinical outcome in human esophageal squamous cell carcinoma. Anticancer Res. 2009:29(4):1233-41.

48. Toschi L, Finocchiaro G, Nguyen TT, Skokan MC, Giordano L, Gianoncelli L, Perrino M, Siracusano L, Di Tommaso L, Infante M, et al. Increased SOX2 gene copy number is associated with FGFR1 and PIK3CA gene gain in nonsmall cell lung cancer and predicts improved survival in early stage disease. PLoS ONE. 2014;9(4), e95303.

49. Wilbertz T, Wagner P, Petersen K, Stiedl AC, Scheble VJ, Maier S, Reischl M, Mikut R, Altorki NK, Moch $\mathrm{H}$, et al. SOX2 gene amplification and protein overexpression are associated with better outcome in squamous cell lung cancer. Mod Pathol. 2011:24(7):944-53.

50. Dogan I, Kawabata S, Bergbower E, Gills JJ, Ekmekci A, Wilson W, 3rd, Rudin CM, Dennis PA. SOX2 expression is an early event in a murine model of EGFR mutant lung cancer and promotes proliferation of a subset of EGFR mutant lung adenocarcinoma cell lines. Lung Cancer. 2014;85(1):1-6.

51. Chen $Y$, Huang $Y$, Huang $Y$, Chen J, Wang S, Zhou J. The prognostic value of SOX2 expression in non-small cell lung cancer: a meta-analysis. PLoS ONE. 2013;8(8), e71140

52. Velcheti V, Schalper K, Yao X, Cheng H, Kocoglu M, Dhodapkar K, Deng Y, Gettinger S, Rimm DL. High SOX2 levels predict better outcome in nonsmall cell lung carcinomas. PLoS ONE. 2013;8(4), e61427.

53. Dhodapkar KM, Gettinger SN, Das R, Zebroski H, Dhodapkar MV. SOX2 specific adaptive immunity and response to immunotherapy in non-small cell lung cancer. Oncoimmunology. 2013;2(7), e25205.

54. Niu CS, Li DX, Liu YH, Fu XM, Tang SF, Li J. Expression of NANOG in human gliomas and its relationship with undifferentiated glioma cells. Oncol Rep. 2011;26(3):593-601.

55. Ensemble [http://uswest.ensembl.org/index.html]

56. RefSeq [http://www.ncbi.nlm.nih.gov/nuccore?LinkName=gene_nuccore_ refsegrna\&from uid $=5460$

57. Nichols J, Zevnik B, Anastassiadis K, Niwa H, Klewe-Nebenius D, Chambers I, Scholer H, Smith A. Formation of pluripotent stem cells in the mammalian embryo depends on the POU transcription factor Oct4. Cell. 1998;95(3):379-91.

58. Scholer HR, Ciesiolka T, Gruss P. A nexus between Oct-4 and E1A: implications for gene regulation in embryonic stem cells. Cell. 1991;66(2):291-304.
59. Boyer LA, Lee TI, Cole MF, Johnstone SE, Levine SS, Zucker JP, Guenther MG, Kumar RM, Murray HL, Jenner RG, et al. Core transcriptional regulatory circuitry in human embryonic stem cells. Cell. 2005;122(6):947-56.

60. Chen X, Xu H, Yuan P, Fang F, Huss M, Vega VB, Wong E, Orlov YL, Zhang $W$, Jiang J, et al. Integration of external signaling pathways with the core transcriptional network in embryonic stem cells. Cell. 2008;133(6):1106-17.

61. Ambrosetti DC, Scholer HR, Dailey L, Basilico C. Modulation of the activity of multiple transcriptional activation domains by the DNA binding domains mediates the synergistic action of Sox2 and Oct-3 on the fibroblast growth factor-4 enhancer. J Biol Chem. 2000;275(30):23387-97.

62. Kuroda T, Tada M, Kubota H, Kimura H, Hatano SY, Suemori H, Nakatsuji N, Tada T. Octamer and Sox elements are required for transcriptional cis regulation of Nanog gene expression. Mol Cell Biol. 2005;25(6):2475-85.

63. Do HJ, Lee WY, Lim HY, Oh JH, Kim DK, Kim JH, Kim T, Kim JH. Two potent transactivation domains in the C-terminal region of human NANOG mediate transcriptional activation in human embryonic carcinoma cells. J Cell Biochem. 2009;106(6):1079-89.

64. Chew JL, Loh YH, Zhang W, Chen X, Tam WL, Yeap LS, Li P, Ang YS, Lim B, Robson $\mathrm{P}$, et al. Reciprocal transcriptional regulation of Pou5f1 and Sox2 via the Oct4/Sox2 complex in embryonic stem cells. Mol Cell Biol. 2005;25(14): 6031-46.

65. Xie Z, Tan G, Ding M, Dong D, Chen T, Meng X, Huang X, Tan Y. Foxm1 transcription factor is required for maintenance of pluripotency of P19 embryonal carcinoma cells. Nucleic Acids Res. 2010;38(22):8027-38.

66. Jerabek S, Merino F, Scholer HR, Cojocaru V. OCT4: dynamic DNA binding pioneers stem cell pluripotency. Biochim Biophys Acta. 2014;1839(3):138-54

67. Chiou SH, Wang ML, Chou YT, Chen CJ, Hong CF, Hsieh WJ, Chang HT, Chen YS, Lin TW, Hsu HS, et al. Coexpression of Oct4 and Nanog enhances malignancy in lung adenocarcinoma by inducing cancer stem cell-like properties and epithelial-mesenchymal transdifferentiation. Cancer Res. 2010;70(24):10433-44.

68. Mitsui K, Tokuzawa Y, Itoh H, Segawa K, Murakami M, Takahashi K, Maruyama M, Maeda M, Yamanaka S. The homeoprotein Nanog is required for maintenance of pluripotency in mouse epiblast and ES cells. Cell. 2003; 113(5):631-42.

69. Booth HA, Holland PW. Eleven daughters of NANOG. Genomics. 2004; 84(2):229-38.

70. Ibrahim EE, Babaei-Jadidi R, Saadeddin A, Spencer-Dene B, Hossaini S, Abuzinadah M, Li N, Fadhil W, llyas M, Bonnet D, et al. Embryonic NANOG activity defines colorectal cancer stem cells and modulates through AP1- and TCF-dependent mechanisms. Stem Cells. 2012;30(10): 2076-87.

71. Zhang J, Wang X, Li M, Han J, Chen B, Wang B, Dai J. NANOGP8 is a retrogene expressed in cancers. FEBS J. 2006;273(8):1723-30.

72. Fairbanks DJ, Fairbanks AD, Ogden TH, Parker GJ, Maughan PJ. NANOGP8: evolution of a human-specific retro-oncogene. G3 (Bethesda). 2012:2(11):1447-57.

73. Chambers I, Colby D, Robertson M, Nichols J, Lee S, Tweedie S, Smith A. Functional expression cloning of Nanog, a pluripotency sustaining factor in embryonic stem cells. Cell. 2003;113(5):643-55.

74. Fu TY, Hsieh IC, Cheng JT, Tsai MH, Hou YY, Lee JH, et al. Association of OCT4, SOX2, and NANOG expression with oral squamous cell carcinoma progression. J Oral Pathol Med. 2015.

75. Han J, Zhang F, Yu M, Zhao P, Ji W, Zhang H, Wu B, Wang Y, Niu R. RNA interference-mediated silencing of NANOG reduces cell proliferation and induces G0/G1 cell cycle arrest in breast cancer cells. Cancer Lett. 2012; 321(1):80-8.

76. Choi SC, Choi JH, Park CY, Ahn CM, Hong SJ, Lim DS. Nanog regulates molecules involved in stemness and cell cycle-signaling pathway for maintenance of pluripotency of P19 embryonal carcinoma stem cells. J Cell Physiol. 2012;227(11):3678-92.

77. Jeter CR, Liu B, Liu X, Chen X, Liu C, Calhoun-Davis T, Repass J, Zaehres H, Shen JJ, Tang DG. NANOG promotes cancer stem cell characteristics and prostate cancer resistance to androgen deprivation. Oncogene. 2011;30(36): 3833-45.

78. Moon JH, Kwon S, Jun EK, Kim A, Whang KY, Kim H, Oh S, Yoon BS, You S. Nanog-induced dedifferentiation of p53-deficient mouse astrocytes into brain cancer stem-like cells. Biochem Biophys Res Commun. 2011;412(1): 175-81.

79. Bourguignon LY, Earle C, Wong G, Spevak CC, Krueger K. Stem cell marker (Nanog) and Stat-3 signaling promote MicroRNA-21 expression and 
chemoresistance in hyaluronan/CD44-activated head and neck squamous cell carcinoma cells. Oncogene. 2012;31(2):149-60.

80. Bourillot PY, Aksoy I, Schreiber V, Wianny F, Schulz H, Hummel O, Hubner N, Savatier P. Novel STAT3 target genes exert distinct roles in the inhibition of mesoderm and endoderm differentiation in cooperation with Nanog. Stem Cells. 2009;27(8):1760-71

81. Po A, Ferretti E, Miele E, De Smaele E, Paganelli A, Canettieri G, Coni S, Di Marcotullio L, Biffoni M, Massimi L, et al. Hedgehog controls neural stem cells through p53-independent regulation of Nanog. EMBO J. 2010;29(15): 2646-58.

82. Golubovskaya VM. FAK and Nanog cross talk with p53 in cancer stem cells. Anticancer Agents Med Chem. 2013;13(4):576-80.

83. Suzuki A, Raya A, Kawakami Y, Morita M, Matsui T, Nakashima K, Gage FH, Rodriguez-Esteban C, Izpisua Belmonte JC. Nanog binds to Smad1 and blocks bone morphogenetic protein-induced differentiation of embryonic stem cells. Proc Natl Acad Sci U S A. 2006;103(27):10294-9.

84. Siu MK, Wong ES, Kong DS, Chan HY, Jiang L, Wong OG, Lam EW, Chan KK, Ngan HY, Le XF, et al. Stem cell transcription factor NANOG controls cell migration and invasion via dysregulation of E-cadherin and FoxJ1 and contributes to adverse clinical outcome in ovarian cancers. Oncogene. 2013; 32(30):3500-9.

85. Nagata T, Shimada Y, Sekine S, Hori R, Matsui K, Okumura T, Sawada S, Fukuoka J, Tsukada K. Prognostic significance of NANOG and KLF4 for breast cancer. Breast Cancer. 2014;21(1):96-101.

86. Lee M, Nam EJ, Kim SW, Kim S, Kim JH, Kim YT. Prognostic impact of the cancer stem cell-related marker NANOG in ovarian serous carcinoma. Int J Gynecol Cancer. 2012;22(9):1489-96.

87. Meng HM, Zheng P, Wang XY, Liu C, Sui HM, Wu SJ, Zhou J, Ding YQ, Li J. Over-expression of Nanog predicts tumor progression and poor prognosis in colorectal cancer. Cancer Biol Ther. 2010;9(4):295-302.

88. Raaphorst FM. Deregulated expression of Polycomb-group oncogenes in human malignant lymphomas and epithelial tumors. Hum Mol Genet. 2005; 14(Spec No 1):R93-100

89. Huber GF, Albinger-Hegyi A, Soltermann A, Roessle M, Graf N, Haerle SK, Holzmann D, Moch H, Hegyi I. Expression patterns of Bmi-1 and p16 significantly correlate with overall, disease-specific, and recurrence-free survival in oropharyngeal squamous cell carcinoma. Cancer. 2011;117(20): 4659-70.

90. Nowak K, Kerl K, Fehr D, Kramps C, Gessner C, Killmer K, Samans B, Berwanger B, Christiansen H, Lutz W. BMI1 is a target gene of E2F-1 and is strongly expressed in primary neuroblastomas. Nucleic Acids Res. 2006;34(6): $1745-54$.

91. Shafaroudi AM, Mowla SJ, Ziaee SA, Bahrami AR, Atlasi Y, Malakootian M. Overexpression of BMI1, a polycomb group repressor protein, in bladder tumors: a preliminary report. Urol J. 2008;5(2):99-105.

92. Fasano CA, Dimos JT, Ivanova NB, Lowry N, Lemischka IR, Temple S. shRNA knockdown of Bmi-1 reveals a critical role for p21-Rb pathway in NSC selfrenewal during development. Cell Stem Cell. 2007;1 (1):87-99.

93. Yadirgi $G$, Leinster V, Acquati S, Bhagat $H$, Shakhova O, Marino S. Conditional activation of Bmi1 expression regulates self-renewal, apoptosis, and differentiation of neural stem/progenitor cells in vitro and in vivo. Stem Cells. 2011;29(4):700-12.

94. Oguro H, Yuan J, Ichikawa H, Ikawa T, Yamazaki S, Kawamoto H, Nakauchi H, Iwama A. Poised lineage specification in multipotential hematopoietic stem and progenitor cells by the polycomb protein Bmi1. Cell Stem Cell. 2010;6(3): 279-86.

95. Lukacs RU, Memarzadeh $\mathrm{S}, \mathrm{Wu} \mathrm{H}$, Witte ON. Bmi-1 is a crucial regulator of prostate stem cell self-renewal and malignant transformation. Cell Stem Cell. 2010;7(6):682-93

96. Lessard J, Sauvageau G. Bmi-1 determines the proliferative capacity of normal and leukaemic stem cells. Nature. 2003;423(6937):255-60.

97. Molofsky AV, He S, Bydon M, Morrison SJ, Pardal R. Bmi-1 promotes neural stem cell self-renewal and neural development but not mouse growth and survival by repressing the p16Ink4a and p19Arf senescence pathways. Genes Dev. 2005;19(12):1432-7.

98. Park IK, Morrison SJ, Clarke MF. Bmi1, stem cells, and senescence regulation. J Clin Invest. 2004;113(2):175-9.

99. Dimri GP, Martinez JL, Jacobs JJ, Keblusek P, Itahana K, Van Lohuizen M, Campisi J, Wazer DE, Band V. The Bmi-1 oncogene induces telomerase activity and immortalizes human mammary epithelial cells. Cancer Res. 2002;62(16):4736-45
100. Song LB, Li J, Liao WT, Feng Y, Yu CP, Hu LJ, Kong QL, Xu LH, Zhang X, Liu $\mathrm{WL}$, et al. The polycomb group protein Bmi-1 represses the tumor suppressor PTEN and induces epithelial-mesenchymal transition in human nasopharyngeal epithelial cells. J Clin Invest. 2009;119(12):3626-36.

101. Dong P, Kaneuchi M, Watari H, Hamada J, Sudo S, Ju J, Sakuragi N. MicroRNA-194 inhibits epithelial to mesenchymal transition of endometrial cancer cells by targeting oncogene BMI-1. Mol Cancer. 2011;10:99.

102. Storci G, Sansone P, Trere D, Tavolari S, Taffurelli M, Ceccarelli C, Guarnieri T, Paterini P, Pariali M, Montanaro L, et al. The basal-like breast carcinoma phenotype is regulated by SLUG gene expression. J Pathol. 2008;214(1):25-37.

103. Yang MH, Hsu DS, Wang HW, Wang HJ, Lan HY, Yang WH, Huang CH, Kao SY, Tzeng CH, Tai SK, et al. Bmi1 is essential in Twist1-induced epithelialmesenchymal transition. Nat Cell Biol. 2010;12(10):982-92.

104. Paranjape AN, Balaji SA, Mandal T, Krushik EV, Nagaraj P, Mukherjee G, Rangarajan A. Bmi1 regulates self-renewal and epithelial to mesenchymal transition in breast cancer cells through Nanog. BMC Cancer. 2014;14:785.

105. Wicha MS. Targeting self-renewal, an Achilles' heel of cancer stem cells. Nat Med. 2014;20(1):14-5.

106. Liu S, Dontu G, Mantle ID, Patel S, Ahn NS, Jackson KW, Suri P, Wicha MS. Hedgehog signaling and Bmi-1 regulate self-renewal of normal and malignant human mammary stem cells. Cancer Res. 2006;66(12):6063-71.

107. Mohty M, Yong AS, Szydlo RM, Apperley JF, Melo JV. The polycomb group BMl1 gene is a molecular marker for predicting prognosis of chronic myeloid leukemia. Blood. 2007;1 10(1):380-3.

108. Song LB, Zeng MS, Liao WT, Zhang L, Mo HY, Liu WL, Shao JY, Wu QL, Li $M Z$, Xia YF, et al. Bmi-1 is a novel molecular marker of nasopharyngeal carcinoma progression and immortalizes primary human nasopharyngeal epithelial cells. Cancer Res. 2006;66(12):6225-32.

109. Vormittag L, Thurnher D, Geleff S, Pammer J, Heiduschka G, Brunner M, Grasl M, Erovic BM. Co-expression of Bmi-1 and podoplanin predicts overall survival in patients with squamous cell carcinoma of the head and neck treated with radio(chemo)therapy. Int J Radiat Oncol Biol Phys. 2009;73(3):913-8.

110. Li J, Gong LY, Song LB, Jiang LL, Liu LP, Wu J, Yuan J, Cai JC, He M, Wang L, et al. Oncoprotein Bmi-1 renders apoptotic resistance to glioma cells through activation of the IKK-nuclear factor-kappaB Pathway. Am J Pathol. 2010;176(2):699-709.

111. van Kemenade FJ, Raaphorst FM, Blokzil T, Fieret E, Hamer KM, Satijn DP, Otte AP, Meijer CJ. Coexpression of BMI-1 and EZH2 polycomb-group proteins is associated with cycling cells and degree of malignancy in B-cell non-Hodgkin lymphoma. Blood. 2001;97(12):3896-901.

112. Piva M, Domenici G, Iriondo O, Rabano M, Simoes BM, Comaills V, Barredo I, Lopez-Ruiz JA, Zabalza I, Kypta R, et al. Sox2 promotes tamoxifen resistance in breast cancer cells. EMBO Mol Med. 2014;6(1):66-79.

113. Yang L, Zhang X, Zhang M, Zhang J, Sheng Y, Sun X, Chen Q, Wang LX. Increased Nanog expression promotes tumor development and Cisplatin resistance in human esophageal cancer cells. Cell Physiol Biochem. 2012;30(4):943-52

114. Du Y, Shi L, Wang T, Liu Z, Wang Z. Nanog siRNA plus Cisplatin may enhance the sensitivity of chemotherapy in esophageal cancer. J Cancer Res Clin Oncol. 2012;138(10):1759-67.

115. Tsai LL, Yu CC, Chang YC, Yu CH, Chou MY. Markedly increased Oct4 and Nanog expression correlates with cisplatin resistance in oral squamous cell carcinoma. J Oral Pathol Med. 2011;40(8):621-8.

116. Crea F, Duhagon Serrat MA, Hurt EM, Thomas SB, Danesi R, Farrar WL. BMI1 silencing enhances docetaxel activity and impairs antioxidant response in prostate cancer. Int J Cancer. 2011;128(8):1946-54.

117. Zhang S, Balch C, Chan MW, Lai HC, Matei D, Schilder JM, Yan PS, Huang TH, Nephew KP. Identification and characterization of ovarian cancer-initiating cells from primary human tumors. Cancer Res. 2008; 68(11):4311-20.

118. Wang E, Bhattacharyya S, Szabolcs A, Rodriguez-Aguayo C, Jennings NB, Lopez-Berestein G, Mukherjee P, Sood AK, Bhattacharya R. Enhancing chemotherapy response with Bmi-1 silencing in ovarian cancer. PLOS ONE. 2011;6(3), e17918.

119. Yin T, Wei H, Gou S, Shi P, Yang Z, Zhao G, Wang C. Cancer stem-like cells enriched in Panc-1 spheres possess increased migration ability and resistance to gemcitabine. Int J Mol Sci. 2011;12(3):1595-604.

120. Shi Y, Seto E, Chang LS, Shenk T. Transcriptional repression by YY1, a human GLI-Kruppel-related protein, and relief of repression by adenovirus E1A protein. Cell. 1991;67(2):377-88. 
121. Park K, Atchison ML. Isolation of a candidate repressor/activator, NF-E1 (YY1, delta), that binds to the immunoglobulin kappa $3^{\prime}$ enhancer and the immunoglobulin heavy-chain mu E1 site. Proc Natl Acad Sci U S A. 1991; 88(21):9804-8.

122. Hariharan N, Kelley DE, Perry RP. Delta, a transcription factor that binds to downstream elements in several polymerase II promoters, is a functionally versatile zinc finger protein. Proc Natl Acad Sci U S A. 1991;88(21):9799-803.

123. Flanagan JR, Becker KG, Ennist DL, Gleason SL, Driggers PH, Levi BZ, Appella E, Ozato K. Cloning of a negative transcription factor that binds to the upstream conserved region of Moloney murine leukemia virus. Mol Cell Biol. 1992;12(1):38-44.

124. Thomas MJ, Seto E. Unlocking the mechanisms of transcription factor YY1: are chromatin modifying enzymes the key? Gene. 1999;236(2):197-208.

125. Shi Y, Lee JS, Galvin KM. Everything you have ever wanted to know about Yin Yang 1. Biochim Biophys Acta. 1997;1332(2):F49-66.

126. Liu H, Shi Y. Yin Yang 1. In: luchi S, Kuldell N, editors. Zinc Finger Proteins: From Atomic Contact to Cellular Function. 1st ed. New York: Springer US; 2005. p. 182-94.

127. Gordon S, Akopyan G, Garban H, Bonavida B. Transcription factor YY1: structure, function, and therapeutic implications in cancer biology. Oncogene. 2006;25(8):1125-42.

128. Wilkinson FH, Park K, Atchison ML. Polycomb recruitment to DNA in vivo by the YY1 REPO domain. Proc Natl Acad Sci U S A. 2006;103(51):19296-301.

129. Thomassen M, Tan Q, Kruse TA. Gene expression meta-analysis identifies metastatic pathways and transcription factors in breast cancer. BMC Cancer. 2008;8:394.

130. Wan M, Huang W, Kute TE, Miller LD, Zhang Q, Hatcher H, Wang J, Stovall $\mathrm{DB}$, Russell GB, Cao PD, et al. Yin Yang 1 plays an essential role in breast cancer and negatively regulates p27. Am J Pathol. 2012;180(5):2120-33.

131. Chinnappan D, Xiao D, Ratnasari A, Andry C, King TC, Weber HC. Transcription factor YY1 expression in human gastrointestinal cancer cells. Int J Oncol. 2009;34(5):1417-23.

132. Kang W, Tong JH, Chan AW, Zhao J, Dong Y, Wang S, Yang W, Sin FM, Ng SS, Yu J, et al. Yin Yang 1 contributes to gastric carcinogenesis and its nuclear expression correlates with shorter survival in patients with early stage gastric adenocarcinoma. J Transl Med. 2014;12:80.

133. Seligson D, Horvath S, Huerta-Yepez S, Hanna S, Garban H, Roberts A, Shi T, Liu X, Chia D, Goodglick L, et al. Expression of transcription factor Yin Yang 1 in prostate cancer. Int J Oncol. 2005;27(1):131-41.

134. Bonavida B, Kaufhold S. Prognostic significance of YY1 protein expression and mRNA levels by bioinformatics analysis in human cancers: a therapeutic target. Pharmacol Ther. 2015;150:149-68.

135. Gao F, Wei Z, An W, Wang K, Lu W. The interactomes of POU5F1 and SOX2 enhancers in human embryonic stem cells. Sci Rep. 2013;3:1588.

136. Wang AM, Huang TT, Hsu KW, Huang KH, Fang WL, Yang MH, Lo SS, Chi CW, Lin JJ, Yeh TS. Yin Yang 1 is a target of microRNA-34 family and contributes to gastric carcinogenesis. Oncotarget. 2014;5(13):5002-16.

137. Satijn DP, Hamer KM, den Blaauwen J, Otte AP. The polycomb group protein EED interacts with $Y Y 1$, and both proteins induce neural tissue in Xenopus embryos. Mol Cell Biol. 2001;21(4):1360-9.

138. Uhlen M, Fagerberg L, Hallstrom BM, Lindskog C, Oksvold P, Mardinoglu A, Sivertsson A, Kampf C, Sjostedt E, Asplund A, et al. Proteomics. Tissue-based map of the human proteome. Science. 2015;347(6220):1260419.

139. Human Protein Atlas [http://www.proteinatlas.org/cancer]

140. SABioscience's Text-Mining Application [http://www.sabiosciences.com/ chipqpcrsearch.php?app=TFBS]

141. University of California, Santa Cruz (UCSC) Genome Browser [https:// genome.ucsc.edu]

\section{Submit your next manuscript to BioMed Central and we will help you at every step:}

- We accept pre-submission inquiries

- Our selector tool helps you to find the most relevant journal

- We provide round the clock customer support

- Convenient online submission

- Thorough peer review

- Inclusion in PubMed and all major indexing services

- Maximum visibility for your research

Submit your manuscript at www.biomedcentral.com/submit
C Biomed Central 